\title{
Body Temperature in Five Species of Shrews
}

\author{
Marek GĘBCZYŃSKI
}

\begin{abstract}
Gębczyński M. 1977: Body temperature in five species of shrews. Acta theriol., 22, 35: 521-530 [With 3 Tables \& 2 Figs.].

Body temperatures $\left(T_{B}\right)$ were measured in five species of insectivorous mammals, Sorex minutus, Sorex caecutiens, Sorex araneus, Neomys anomalus and Neomys fodiens. Mean $\mathrm{T}_{\mathrm{B}}$ of shrews ranged from 37.3 to $39.1^{\circ} \mathrm{C}$ varying with species but more so with the age of animals and season when measurements. were made. Daily $\mathrm{T}_{B}$ rhythm in $S$. araneus and $S$. minutus showed amplitudes of $0.6^{\circ} \mathrm{C}$. Low ambient temperature $\left(5^{\circ} \mathrm{C}\right)$ changed the $\mathrm{T}_{\mathrm{B}}$ of shrews from $-1.1^{\circ} \mathrm{C}$ to $+0.5^{\circ} \mathrm{C}$ and at $30^{\circ} \mathrm{C}$ a rise of $\mathrm{T}_{\mathrm{B}}$ from $0.1^{\circ} \mathrm{C}$ to $1.3^{\circ} \mathrm{C}$ was observed. High pre-measurement activity results in an increase of $\mathrm{T}_{\mathrm{B}}$ up to $2^{\circ} \mathrm{C}$ above the normal level. Starvation affects $T_{B}$ in shrews but reversible hypothermy was not observed.

[Mammals Res. Inst., Polish Acad. Sci,, 17-230 Białowieża, Poland]
\end{abstract}

\section{INTRODUCTION}

Of 278 mammalian species for which the $T_{B}$ was listed by A $1 \mathrm{tm}$ a $\mathrm{n}$ \& Dittmer (1968) only seven belong to the Insectivora. This may reflect the scant interest by physiologists for this Order of mammals. Yet this group is important in comparative physiology due to the many species (374), their adaptability to various environments, and the extremely small size of some shrews. Initial body temperatures for two species of shrews were given by Kendeigh (1945). Nevertheless his hypothesis concerning a relatively low $\mathrm{T}_{\mathrm{B}}$ in Blarina brevicauda was not confirmed by the greater amount of data obtained by Dor e m u s (1965) and Neal \& Lustic (1973). The studies of Vogel (1974) unexpectedly indicate that the smallest mammal, Suncus etruscus, undergoes reversible hypothermy. Although $\mathrm{T}_{\mathrm{B}}$ for this species is not known, $\mathrm{T}_{\mathrm{B}}$ for Suncus murinus, a related but much larger form, is within the normal range for mammals ( $\mathrm{Hasler} \& \mathrm{Nalbandov}, 1974$ ). However, Bashenina's (1965) suggestion of reversible hypothermy in Sorex minutus (subfamily Soricinae vs Crocidurinae for Suncus) could not be confirmed by measurements of oxygen consumption ( $\mathrm{G}$ ę bc zyński, 1971). Range of $T_{B}$ in Sorex cinereus is relatively wide $\left(36-41^{\circ} \mathrm{C}\right.$ ) depending on pre-measurement activity (M orrison, R y se r \& D a we, 1959) although torpor was not observed. 
In more detailed studies on shrews belonging to the genus Sorex their specific biology should be considered. Individuals born in a given year are sexually inactive though completely independent from their parents. They achieve sexual maturity after overwintering. Young adults differ from overwintered old adults in many morphological and physiological features (for extensive review see $\mathrm{Pucek}, 1970$ ). Therefore the aim of this study was not only to document $T_{B}$ in several species of European Insectivora but also to analyze whether this parameter depends on age and season. Moreover, observations were made of the influence of different ambient temperatures, activity and starvation on the stability of $T_{B}$ in shrews. This made it possible to determine whether reversible hypothermy occurs in soricine shrews, as it does in crocidurine shrews.

\section{MATERIALS AND METHODS}

A total of 239 insectivores belonging to five species (Table 1) were trapped in different seasons of the year in Białowieża National Park in Northeastern Poland. Live-traps were checked every 2 or 3 hours, usually at night except

\section{Table 1}

Individual insectivores tested by season. Adults were born the previous year and overwintered. Juveniles were born the year they were measured. Body weigths $(\mathrm{g})$ are given in brackets.

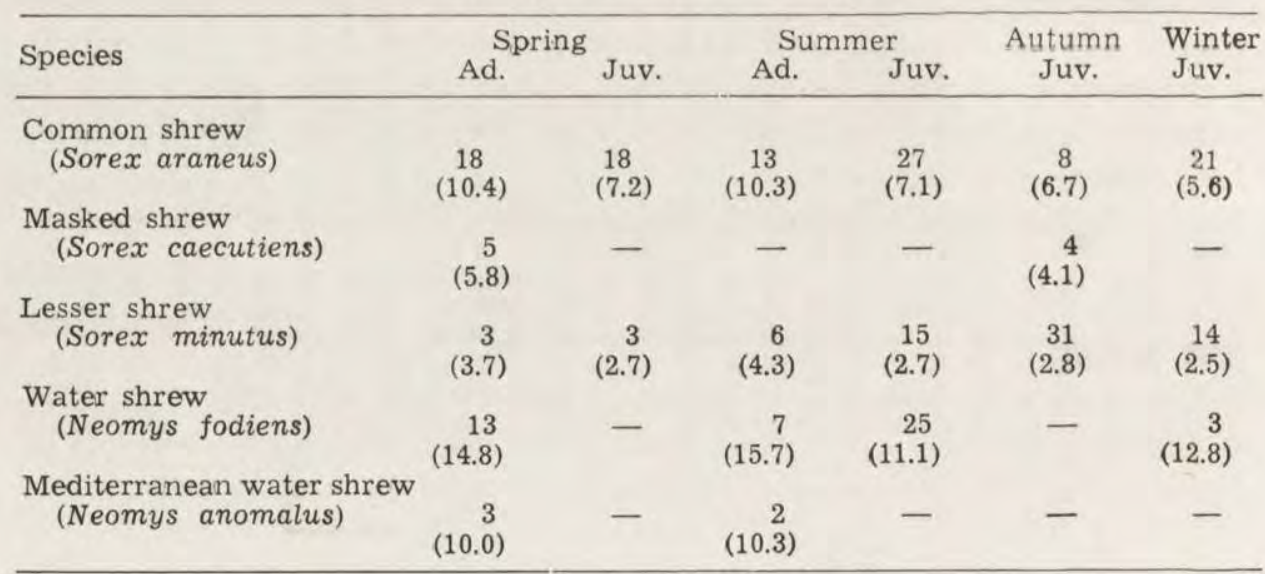

during extreme weather conditions when they were checked only in the evening and morning. Trapped animals were maintained in the laboratory in separate cages containing moss litter. Animals were fed minced meat, Tenebrio larvae and water ad libitum. 
Intial $T_{B}$ measurements were usually made an hour after transporting the animals into the laboratory. Successive determinations were made daily. No significant differences in $T_{B}$ were noted between the first and subsequent measurements. Temperature was measured per rectum by an electric thermometer (Electro-laboratiet, Denmark) accurate to $0.1^{\circ} \mathrm{C}$ using a flexible probe (F6) with a diameter of $0.9 \mathrm{~mm}$ inserted $15 \mathrm{~mm}$ in Sorex minutus and up to $30 \mathrm{~mm}$ in Neomys fodiens, and other shrew species.

\section{RESULTS}

\section{Body Temperature under Normal Conditions}

Sorex araneus. $\mathrm{T}_{\mathrm{B}}$ in the common shrew is variable and dependent on the season and age of the animal. Comparison of $\mathrm{T}_{\mathrm{B}}$ in young adults from several successive seasons shows that the mean value increases from spring to autumn yet the differences between spring ${ }^{1}$ and summerautumn are not statistically significant. It is only the drop observed in winter that is important in comparison with autumn $(P<0.02$, Student's $t$ test; Table 2).

Old adults were caught only in spring and summer. Mean $T_{B}$ in both seasons is nearly the same (Table 2) but $T_{B}$ in both spring and summer animals is significantly lower $(P<0.01)$ compared with young animals in the same season. $T_{B}$ values at variance with the mean were noted in three shrews, all juvenile Sorex araneus, which lived several hours after the initial determination:

1. Winter, $\mathrm{T}_{\mathrm{B}} 34.4^{\circ} \mathrm{C}$ at $7: 30 \mathrm{am}, 36.9^{\circ} \mathrm{C}$ at $2: 00 \mathrm{pm}$.

2. Summer, $\mathrm{T}_{\mathrm{B}} 34.5^{\circ} \mathrm{C}$ at $8: 00 \mathrm{am}, 37.8^{\circ} \mathrm{C}$ at $10: 00 \mathrm{am}$.

3. Summer, $\mathrm{T}_{\mathrm{B}} 34.9^{\circ} \mathrm{C}$ at $8: 00 \mathrm{am}, 38.4^{\circ} \mathrm{C}$ at $11: 00 \mathrm{am}$.

Since $T_{B}$ drops of this magnitude have never been observed in this laboratory I assume that these low temperatures resulted from some unknown effects of trapping.

Sorex caecutiens. Relatively few (9) of these shrews were caught. Yet both old adults from spring and young adults from autumn experienced consistently elevated $\mathrm{T}_{\mathrm{B}}$ in comparison with that of other species of Sorex (Table 2).

Sorex minutus. In this species, as in Sorex araneus, $\mathrm{T}_{\mathrm{B}}$ of young adults is highest in autumn $(P<0.02)$. Also $\mathrm{T}_{\mathrm{B}}$ of old adults in spring and summer is lower than for young adults though the difference $(P<0.01)$ is significant only in summer (Table 2$)$. In only one Sorex

1 In 1975 , when measurement occurred, young of the year were first trapped 28 May, nearly a month earlier than usual. Thus it was possible to compare young adults with overwintered (old) adults during the same season. 


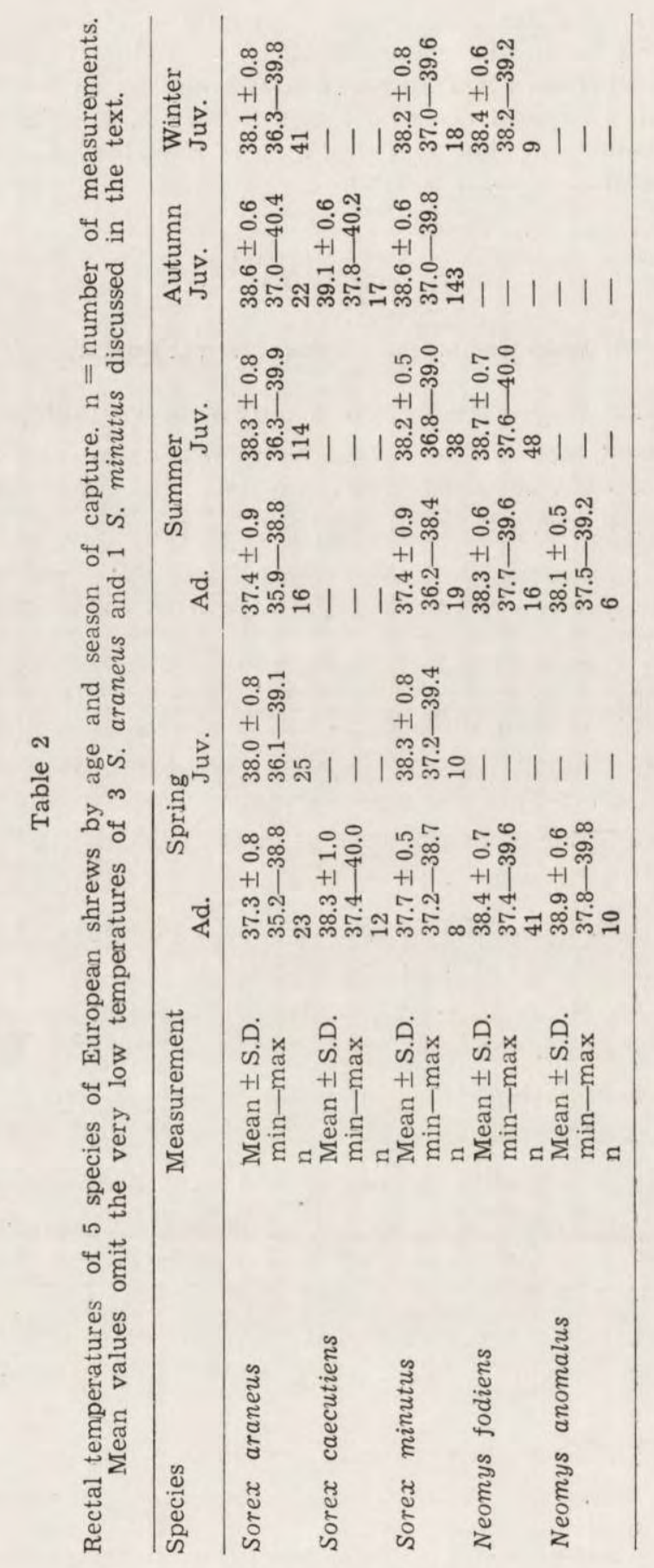


minutus trapped in autumn was $\mathrm{T}_{\mathrm{B}} 35.2^{\circ} \mathrm{C}$; after three hours in the laboratory it rose to $37.4^{\circ} \mathrm{C}$. Similar low, reversible $\mathrm{T}_{\mathrm{B}}$ was not observed in the other species shrews.

Neomys fodiens. The water shrew does not display significant seasonal fluctuations in $\mathrm{T}_{\mathrm{B}}$. Also there are no significant differences between young adults and old adults (Table 2) though in summer $T_{B}$ for old adults is slightly. lower than in shrews born that year.

Neomys anomalus. Individuals of this species were trapped only in spring and summer. The mean $\mathrm{T}_{B}$ in both seasons is high, and for old adults from spring it is even higher than for young adults (Table 2).

\section{Daily $\mathbf{T}_{\mathrm{B}}$ Rhythm}

For $S$. araneus and $S$. minutus $\mathrm{T}_{\mathrm{B}}$ measurements were made every three hours, day and night. Fluctuation were minimal. Maximum $T_{B}$

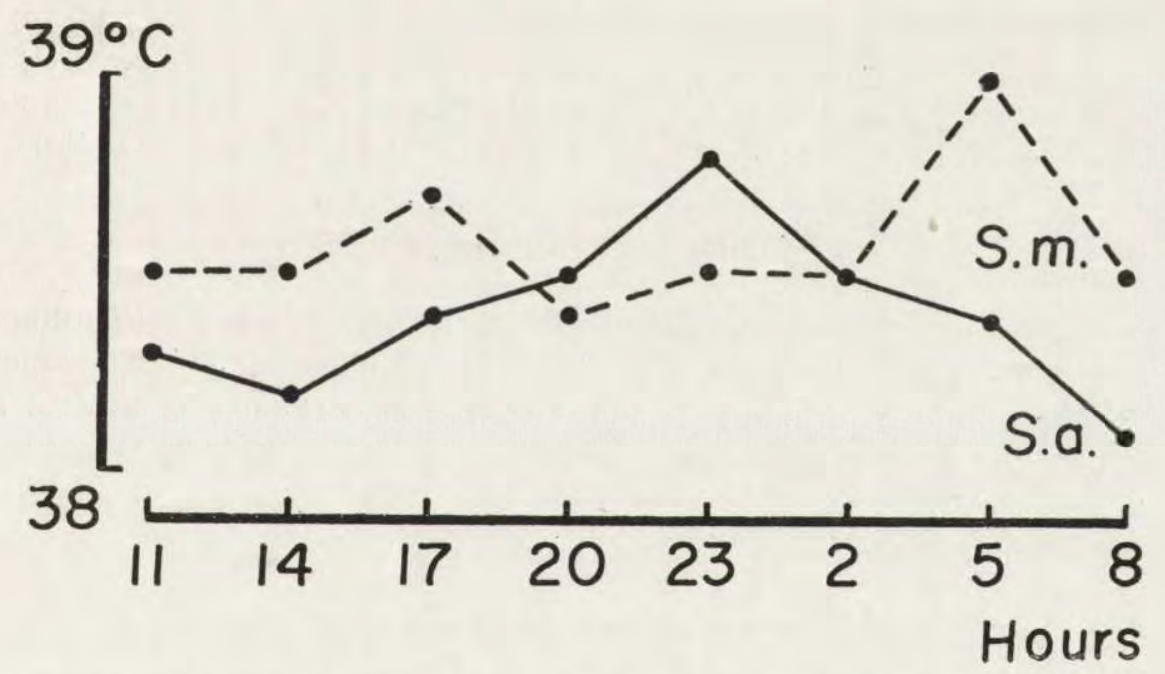

Fig. Daily $T_{n}$ rhythm in the common shrew, Sorex araneus (S.a.), and the lesser shrew, Sorex minutus (S.m.)

$\begin{array}{lcrrrrrrrr}\text { S.m. } & \text { S.D. } & .4 & .3 & .3 & .4 & .5 & .4 & .5 & .5 \\ & \mathrm{n} & 12 & 10 & 10 & 10 & 12 & 6 & 6 & 9 \\ \text { S.a. } & \text { S.D. } & .6 & .4 & .5 & .3 & .5 & .2 & .4 & .5 \\ & \mathrm{n} & 16 & 16 & 15 & 15 & 15 & 7 & 9 & 16\end{array}$

of $38.8^{\circ} \mathrm{C}$ for the common shrew occurred at $11 \mathrm{pm}$ and decreased to $38.2^{\circ} \mathrm{C}$ between 8 am and $2 \mathrm{pm}$. Lesser shrews' mean daily differential is also $0.6^{\circ} \mathrm{C}$ but the rhythm of this variation differs from that of the other species since it is maximal between $5 \mathrm{pm}$ and 5 am (Fig. 1). 


\section{Influence of Ambient Temperature on $T_{B}$}

Shrews were kept for three hours with access to food at ambient temperatures of approximately $5^{\circ} \mathrm{C}$ or $30^{\circ} \mathrm{C}$. Body temperatures were measured immediately before and after this period. At $5^{\circ} \mathrm{C} \mathrm{T}_{\mathrm{B}}$ falls, but not in all cases. $N$. fodiens from spring and $S$. areneus from winter show a rise in $\mathrm{T}_{\mathrm{B}}$, about $0.1^{\circ} \mathrm{C}$ and $0.5^{\circ} \mathrm{C}$, respectively (Table 3 ). Conversely, all shrews tested at $30^{\circ} \mathrm{C}$ experienced elevated mean $\mathrm{T}_{\mathrm{B}}$. This rise is quite remarkable, amounting from $0.5^{\circ} \mathrm{C}$ to $1.3^{\circ} \mathrm{C}$ except for $N$. fodiens in the spring $\left(0.1^{\circ} \mathrm{C}\right)$ (Table 3$)$.

Table 3

Influence of ambient temperature on $T_{B}$ in five species of shrews caught in different seasons. $n=$ number of measurements; $-=$ drop of $T_{B} ;+=$ rise of $T_{B}$.

\begin{tabular}{llrllll}
\hline Species & Season, age & $\mathrm{n}$ & at $5 \mathrm{C}$ & $\mathrm{n}$ & at $30 \mathrm{C}$ \\
\hline Sorex araneus & summer, juv. & 3 & $-1.1(37.2)$ & 6 & $+0.7(39.0 \pm 0.3)$ \\
& winter, juv. & 4 & $+0.5(38.6 \pm 0.2)$ & 3 & $+1.3(39.4)$ \\
Sorex caecutiens & autumn, juv. & 2 & $-0.1(39.0)$ & 4 & $+1.2(40.3 \pm 0.2)$ \\
Sorex minutus & summer, juv. & 3 & $-0.3(37.9)$ & 3 & $+0.7(38.9)$ \\
& autumn, juv. & 18 & $-0.7(37.9 \pm 0.6)$ & 13 & $+0.5(39.1 \pm 0.5)$ \\
Neomys fodiens & spring, ad. & 6 & $+0.1(38.5 \pm 0.4)$ & 6 & $+0.1(38.5 \pm 0.8)$ \\
Neomys anomalus & spring, ad. & 4 & $-0.8(38.1 \pm 0.5)$ & 3 & $+0.7(39.6)$ \\
\hline
\end{tabular}

\section{Influence of Activity on $T_{B}$}

$S$. araneus and $S$. minutus forced to run in a cage for 5 to 7 minutes prior to $T_{B}$ determinations responded with elevated $T_{B}$. The mean $\mathrm{T}_{\mathrm{B}}$ of 7 juvenile $S$. araneus in summer was $39.6^{\circ} \mathrm{C}\left(39.0^{\circ} \mathrm{C}\right.$ to $\left.40.3^{\circ} \mathrm{C}\right)$. That of 4 juvenile S. minutus was $40.0^{\circ} \mathrm{C}\left(39.7^{\circ} \mathrm{C}\right.$ to $\left.40.6^{\circ} \mathrm{C}\right)$ in autumn. Thus average $\mathrm{T}_{\mathrm{B}}$ elevations were respectively $1.3^{\circ} \mathrm{C}$ and $2.0^{\circ} \mathrm{C}$ compared with seasonal means.

\section{Starvation and $T_{B}$}

Sorex araneus deprived of food were initially hyperactive, resulting in elevated $\mathrm{T}_{\mathrm{B}}$. After this, they experienced either stationary or depressed $\mathrm{T}_{\mathrm{B}}$ (Fig. 2A). In $S$. caecutiens a slight drop in $\mathrm{T}_{\mathrm{B}}$ was observed during the first 5 hours after food deprivation. After 7 hours $T_{B}$ dropped considerably, body movements decreased, and the animals refused offered food.

Starvation of $18 \mathrm{~S}$. minutus for 2 hours did not alter their mean $\mathrm{T}_{\mathrm{B}}$. However, two adult $S$. minutus observed in the spring had elevated $\mathrm{T}_{\mathrm{B}}$ following intense activity. Subsequently both died nearly simultane- 
ously. These two shrews may be considered exceptional since others ubserved in autumn endured 7 hours of starvation. Then their $T_{B}$ increased slightly for 5 hours after food removal then plateaued (Fig. 2B).

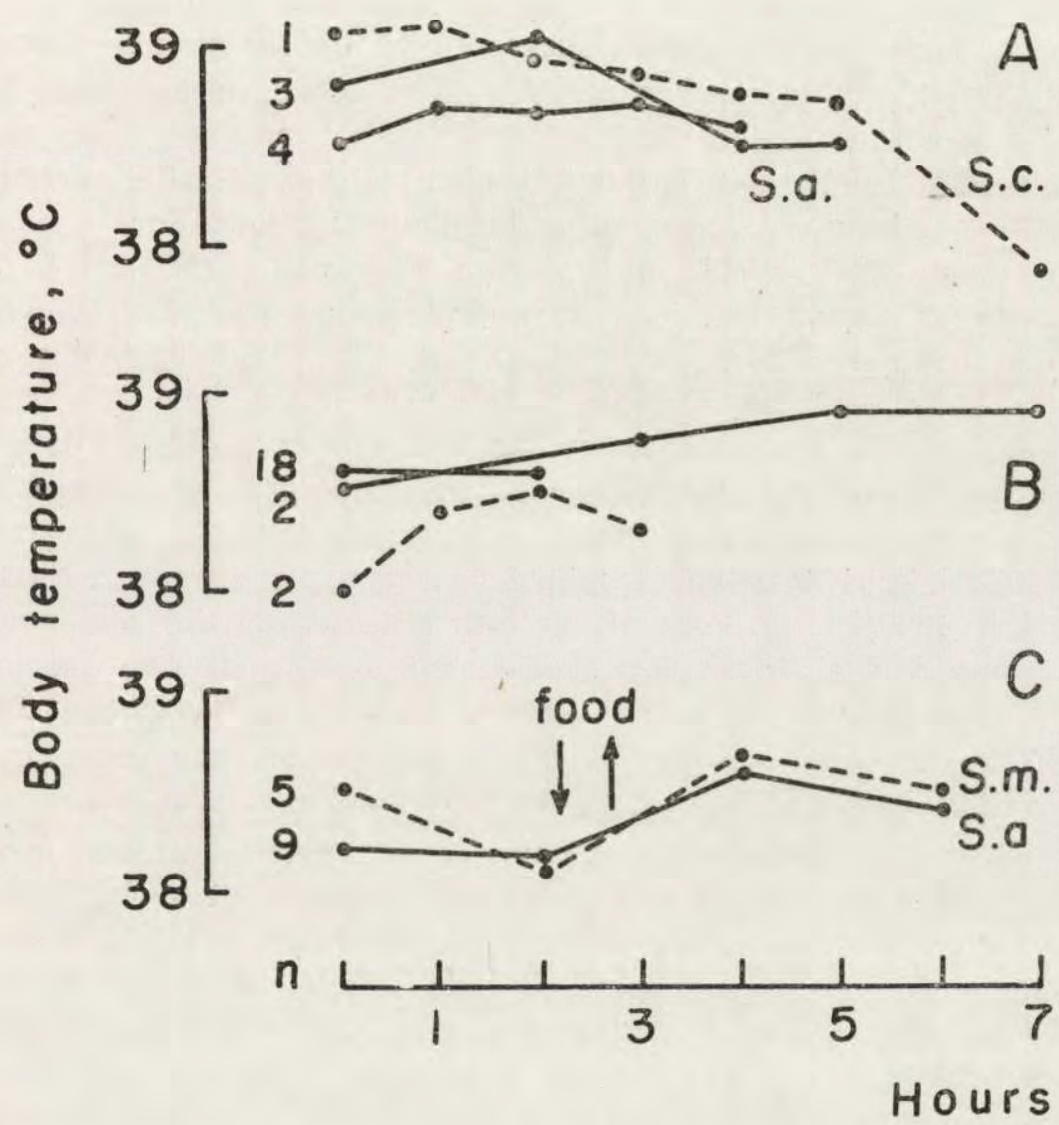

Fig. 2. Influence of starvation on $\mathrm{T}_{\mathrm{B}}$ in three species of shrews.

A. Sorex caecutiens (S.c.), autumn; Sorex araneus (S.a), spring ( $n=3$ juv., 4 ad.), B. Sorex minutus (S.m.); continuous line $=$ autumn, broken line $=$ spring. C. Sore $x$ minutus and Sorex araneus. After 2 hours without food, food was offered for 30 minutes and then removed.

Two series of measurements were made on starved $S$. araneus and S. minutus. During this time they were offered food for 30 minutes only. The first 2 hours without food did not cause $T_{B}$ change of $S$. araneus but in $S$. minutus, $\mathrm{T}_{\mathrm{B}}$ dropped. Food consumption was followed by $\mathrm{T}_{\mathrm{B}}$ rises in both species, after which their temperature again fell (Fig. 2C). 


\section{DISCUSSION}

Body temperature, a fundamental parameter in bioenergetics, is relatively easy to determine but data exist for about $7 \%$ of the mammalian species and these data are often not in agreement. Morrison \& Ryser (1952) demonstrated that $T_{B}$ in mammals is apparently independent of body weight. Nevertheless, $T_{B}$ is unquestionably connected with the metabolic level characteristic of a given species ( $\mathrm{M} c \mathrm{Nab}$, 1966). Since shrews are characterized by high heat production rate it may be assumed that their $T_{B}$ is correspondingly great. This assumption has, however, been only partially documented. Both Sorex cinereus (Morrison et al., 1959) and Blarina brevicauda (Neal \& Lustick, 1973) occupy positions in the upper part of the known $T_{B}$ range for mammals. The present data demonstrate that $T_{B}$ in European shrews are correspondingly high. Differences among the five species studied are small, although in spring and summer, old, adult Sorex uraneus and $S$. minutus have lower $\mathrm{T}_{\mathrm{B}}$ in comparison with three other species. The lower $\mathrm{T}_{\mathrm{B}}$ of old adults compared with that of young adults of the same species may be explained by metabolic differences ( $\mathrm{G}$ ę bc zynski, 1965). It is more difficult to account for the seasonal differences observed in these two species but $T_{B}$ for all five species of shrews, regardless of age and season, is generally between $37.3^{\circ} \mathrm{C}$ and $39.1^{\circ} \mathrm{C} . \mathrm{T}_{\mathrm{B}}$ in 14 of the 19 age-season groups studies is in the range of $38.0^{\circ} \mathrm{C}$ to $38.7^{\circ} \mathrm{C}$.

The effect of experimental starvation on $T_{B}$ is not uniform, initially resulting in both a rise of and a drop in $\mathrm{T}_{\mathrm{B}}$, as well as lack of any change. In Sorex minutus, starvation for three hours resulted in nearly simultaneous death of two animals, yet two others lived 7 hours without nourishment. This ability to withstand starvation is doubtlessly affected by many physical and physiologic parameters (e.g., coprophagy: see Loxton et al., 1975) but no reversible hypothermy was caused by starvation in the laboratory. It must be stressed that shrews can withstand ambient temperature drops to $5^{\circ} \mathrm{C}$ but respond by a slight decrease as well as a slight rise in $\mathrm{T}_{\mathrm{B}}$. However, elevated $\mathrm{T}_{\mathrm{B}}$, often significantly, invariably occurred at $30^{\circ} \mathrm{C}$. Other shrews react to high ambient temperature similarly (M o r r is o n et al., 1973).

It can generally be concluded that shrews are characterized by an ability to maintain temperature constancy within a wide range of ambient temperature. They are also able to survive temporary food deprivation and, though $\mathrm{T}_{\mathrm{B}}$ may fluctuate, reversible hypothermy in the Soricinae is not indicated by the present data. Differences of $T_{B}$ among the species of shrews studied are relatively small. 


\section{REFERENCES}

1. A $1 \mathrm{tman}$ P. L. \& Dittmer D. S. (eds), 1968: Biological Handbaoks, Metabolism. Fed. Am. Soc. Exp. Biol.: 1-737. Bethesda.

2. Bashenina N. V., 1965: O himičeskoj termoreguljacji u melkih nasekomojadnyh (Insectivora, Mammalia). Naučnye Doklady Vysšej Skoly, Biologičeskie Nauki, 4: 43-47.

3. Doremus H. M., 1965: Heart rate, temperature and respiration rate of short-tailed shrews in captivity. J. Mamm., 46, 3: 424 425.

4. Gębczyński M., 1965: Seasonal changes in the metabolism and activity of Sorex araneus Linnae us, 1758. Acta theriol., 10, 22: 303-331.

5. Gębczyński M., 1971: Oxygen consumption in starving shrews. Acta theriol., 16, 17: 288-292.

6. Hasler M. J. \& Nalbandov A. V., 1974: Body and peritesticular temperatures of musk shrew (Suncus murinus). J. Reprod. Fert., 36: 397-399.

7. Kendeigh S. C., 1945: Body temperature of small mammals. J. Mamm., 26, 1: 86-87.

8. Loxton R. G., Raffaelli D. \& Begon M., 1975: Coproghagy and the diurnal cycle of the common shrew, Sorex araneus. J. Zool., Lond., 177: $449-453$.

9. $\mathrm{M} \mathrm{c} \mathrm{Nab}$ B., 1966a: An analysis of the body temperature of birds. Condor, 68, 1: $47-55$.

10. Morrison P: R. \& Ryser F. A., 1952: Weight and body temperature in mammals. Science, 116: $231-232$.

11. Morrison P. R., Ryser F. A. \& Dawe A. R., 1959: Studies on the physiology of the masked shrew Sorex cinereus. Physiol. Zoöl., 32, 4: 256-271.

12. Nea 1 C. M., \& Lustick S. J., 1953: Energetics and evaporative water los in the short-tailed shrew Blarina brevicauda. Physiol. Zoöl., 46, 3: $180-185$.

13. Pucek R., 1970: Seasonal and age changes in shrews as an adaptive process. Symp. Zool. Soc. Lond., 26: 189-207.

14. Voge 1 P., 1974: Kälteresistenz und reversible Hypothermie der Etruskerspitzmaus (Suncus etruscus, Soricidae, Insectivora). Zeitschr. Säugetierkde, 39, 2: $78-88$.

Acknowledgement: I am indebted to Dr. G. L. Dry den for critically reviewing the manuscript and for correcting the English text.

Accepted, June 28, 1977.

\section{Marek GEBCZYŃSKI}

\section{TEMPERATURA CIAEA U PIĘCIU GATUNKOW RYJOWEK}

\section{Streszczenie}

Zmierzono temperaturę ciała u pięciu gatunków drobnych ssaków owadożernych: Sorex minutus, $S$. caecutiens, $S$. araneus, Neomys anomalus, $N$. fodiens; łowionych w różnych porach roku (Tabela 1). Srednia wartość temperatury ciała waha się 
od 37,3 do $39,1^{\circ} \mathrm{C}$ - zależnie od gatunku a przede wszystkim od wieku zwierzęcia i sezonu jego zlowienia (Tabela 2). Dobowy rytm cieploty ciała u $S$. areneus i $S$. minutus wykazuje amplitudę okolo $0,6^{\circ} \mathrm{C}$ (Ryc. 1). Niska temperatura otoczenia $\left(5^{\circ} \mathrm{C}\right)$ zmienia temperaturę ciała ryjówek od $-1,1$ do $+0,5^{\circ} \mathrm{C}$ a przy $30^{\circ} \mathrm{C}$ obserwuje się wzrost od 0,1 do $1,3^{\circ} \mathrm{C}$ (Tabela 3). Duża ruchliwość przed pomiarem, może podnieść temperaturę ciała nawet do $2^{\circ} \mathrm{C}$ powyżej wartości normalnej. Głodzenie ma pewien wpływ na badany wskaźnik (Ryc. 2), ale nie stwierdzono by wywoływało ono odwracalną hipotermię. 